\title{
Duck Plague Virus Antibodies: An Analysis by Indirect ELISA in Duck Population of Assam
}

\author{
Samsun Neher, Nagendra N. Barman, Durlav P. Bora*, Hiramoni Sarmah, Sophia M. \\ Gogoi, Kongkon Baruah, Sukanya Buzarbaruah, Parag J. Saharia and Sailendra K. Das
}

Department of Microbiology, College of Veterinary Science, Assam Agricultural University, Khanapara, Guwahati-781 022, Assam, India

*Corresponding author

\section{A B S T R A C T}

\section{Keywords}

Duck, Duck plague virus, antibodies, Indirect ELISA, Assam

Article Info

Accepted:

15 January 2019

Available Online:

10 February 2019
The present study was undertaken to screen the prevalence of Duck Plague virus (DPV) antibodies among the duck population of Assam. In this study, a total of 445 sera samples were collected from 10 different districts of Assam during August 2014 to November 2015. The sera samples were tested for presence of antibodies against duck plague virus (DPV) by employing Indirect-ELISA. Indirect ELISA was standardized using purified DPV produced in bulk in primary chicken embryo fibroblast (CEF) cell culture. Out of the 445 sera samples tested 291 were found to be positive for DPV antibody revealing a percent positivity of $65.39 \%$. Among the 291 positive sera, 119 (26.74\%), $112(25.17 \%)$ and $60(13.48 \%)$ showed a titre of 1:80, 1:160 and 1:320 respectively. It has been found that duck plague infection is widely prevalent among duck population of different districts of Assam.

\section{Introduction}

Duck keeping is an integral part of rural farming system in India that provides supplementary income to the small, marginal and landless farmers in different states of India including Assam. The distribution and demographic dynamics of duck population revealed that they are concentrated in eastern, north eastern and southern states of the country (Rajput et al., 2014). The leading states in duck population are Assam, West Bengal, Kerala, Andhra Pradesh, Tamil Nadu, UP, Bihar and Orissa (Narahari, 2009). According to the $19^{\text {th }}$ livestock census report of India the total population of duck is 23.54 million and Assam ranks as highest duck populous state of the country having 7.31 million ducks. However optimum productivity is hampered by various epidemics in ducks due to infectious diseases which causes high mortality in duck population. Among the prevailing infectious diseases of ducks in India particularly in Assam, Duck Plague (DP) or Duck Viral Enteritis (DVE) is considered to be highly infectious and contagious disease. It causes devastating outbreaks affecting duck populations and thereby crippling this profit making industry (Jensen, 1968; Wang et al., 
2013). Duck plague (DP) is an acute, contagious, highly pathogenic as well as latent herpesvirus infection of all ages of birds from the order Anseriformes which includes ducks, geese and swans (Leibovitz, 1984; Kaleta et al., 2007; Fadly et al., 2008; ElSamadony et al., 2013). It was first described by Baudet in Netherlands (Baudet, 1923). In India the disease was first reported from West Bengal (Mukherji et al., 1963). The disease is caused by a herpesvirus named duck plague virus (DPV) or Anatid herpes virus 1. According to Ninth International Committee on Taxonomy of Viruses, 2012 the Duck plague virus was grouped under the genus Mardivirus in the subfamily Alphaherpesvirinae of the family Herpesviridae (King et al., 2012; Ahamed et al., 2015). The viral genome is a linear, double-stranded DNA molecule of approximately $180 \mathrm{kbp}$ with a structure similar to other alphaherpes viruses (Fukuchi et al., 1984).

The morbidity and mortality of the birds ranges from 5 to 100 percent (Jensen, 1961; Kaleta et al., 2007; Campagnolo et al., 2001; Aravind et al., 2015). Recovered birds may be latently infected with the virus and shed the virus in the faeces or on the surface of eggs over a period of years (Richther and Horzinek, 1993; Shawky and Schat, 2002). Clinical signs vary with virulence of the virus, the species, immune status, age and sex of the affected birds. Ranges of signs include sudden deaths, photophobia associated with partially closed and pasted eye-lids, polydipsia, loss of appetite, ruffled feathers, ataxia, greenish watery diarrhea, soiled vents and nasal discharge, the overall appearance is weakness and depression (Wang et al., 2013; ElSamadony et al., 2013).

Duck plague is endemic in India particularly in Assam. Outbreaks of Duck Plague have been reported from various parts of the country (Mukherji et al., 1963; Duraiswami et al., 1979; Rajan et al., 1980; Kulkarni et al., 1995) and also from Assam (Chakravarty et al., 1980; John et al., 1990; Konch et al., 2009, Doley, 2012). However, till date no work has been carried out on the seroprevalence of Duck Plague in Assam. In this study, we have reported the prevalence of duck plague viral antibodies in duck population of different places of Assam in order to take effective measures to control the disease which causes huge economic loss to the duck farming industry.

\section{Materials and Methods}

\section{Source of samples}

Sera samples from ducks were collected randomly from unvaccinated 2-3 months old ducks from different districts of Assam. From each of the ducks blood samples were collected in Vacutainer (B D biosciences) by puncturing wing vein. The serum was separated, transferred to small sterile screwcapped plastic vials (Tarsons), labelled properly and stored at $-20^{\circ} \mathrm{C}$ without addition of any preservative till further use.

\section{Adaptation and bulk production of DPV vaccine strain in chicken embryo fibroblast (CEF)}

Chicken embryo adapted duck plague vaccine virus was grown in primary CEF cell culture (OIE, 2008) prepared from 9-11 day-old embryonated hen's eggs. The primary CEF cell monolayers were grown in $25 \mathrm{~cm}^{2}$ tissue culture flasks (Corning) using Eagle's minimum essential medium (Sigma, USA) supplemented with $4 \%$ fetal calf serum (Hyclone, USA), and antibiotic-antimycotic solution (Sigma, USA). The cells were incubated at $37^{\circ} \mathrm{C}$ with $5 \% \mathrm{CO}_{2}$. The chicken embryo-grown freeze-dried duck plague vaccine virus was reconstituted as per the 
guidelines and used for infecting the CEF cells. Virus was adsorbed for $1 \mathrm{hr}$ and then the cell layer was washed with HBSS and submerged in EMEM containing 2\% FCS. Flasks were observed for cytopathic effects (CPE) in phase contrast microscope at $12 \mathrm{~h}$ interval and harvested after 48-72 $\mathrm{h}$ postinfection (p.i.) by three freeze-thaw cycles. Twenty serial passages of the vaccine virus was done and the presence of the virus in each passage was determined by PCR.

\section{Concentration and purification of the duck plague vaccine virus}

For purification of virus about one and half litre of cell culture propagated DPV vaccine was prepared. The virus suspension was initially concentrated and then subjected to sucrose density gradient ultracentrifugation (Clegg et al., 1985). Briefly, cell free supernatant was treated with 0.5 percent PEG6000 (Sigma-Aldrich, USA) in $5 \mathrm{M} \mathrm{NaCl}$ through constant stirring at $4^{\circ} \mathrm{C}$ overnight. Next day, PEG treated virus suspension was centrifuged at $6000 \mathrm{rpm}$ for 45 minutes. Supernatant was removed carefully and pellet was resuspended in $1 / 10^{\text {th }}$ of the original volume with PBS (0.15M, pH7.2). Resuspended virus pellet was preserved at $70^{\circ} \mathrm{C}$ till further use for purification of virus.

Cell culture propagated and PEG concentrated DP virus was purified by following method (Guo et al., 2009). A 4-step discontinuous sucrose density gradient was prepared using sucrose solutions of $30 \%, 40 \%, 50 \%$, and 60 $\%(\mathrm{w} / \mathrm{v})$ in PBS (0.15M, pH7.2). Gradient was prepared sequentially in $8 \mathrm{ml}$ tubes (Quick seal, Beckman) with 30\% at top and $60 \%$ at bottom. Resuspended pellet was overlaid on to $30 \%(\mathrm{w} / \mathrm{v})$ sucrose and sealed the tubes and centrifuged at 45,000 rpm for 2 hours at $4^{\circ} \mathrm{C}$ using ultracentrifuge machine (Beckman Coulter Optima Max). Virus bands in the gradients were observed as bluish white opalescent layer and were recovered from the tubes by side puncturing attaching a strip of cello tape on the point of puncturing. A hypodermic needle mounted on a $5 \mathrm{ml}$ disposable syringe was inserted (bevel side upward) immediately below the posterior of the virus band.

The fluid was slowly withdrawn until most of the virus was removed. Different fractions of individual band were tested by PCR for presence of the virus. Individual pooled gradient fractions were diluted 10 fold with PBS (0.15M, pH 7.2) to reduce the density and centrifuged again at 45,000 rpm $(130,000$ $\times \mathrm{g}$ ) for 1.5 hours at $4^{\circ} \mathrm{C}$. The supernatant was discarded with utmost care to remove completely. The sediment was resuspended with PBS (0.15M, pH 7.2) and stored at $-20^{\circ} \mathrm{C}$ for further use.

The presence of virus in the sediment was confirmed by PCR and protein concentration was estimated using Spectrophotometer (Eppendorf, Germany). The viability of the purified virus in each fraction was confirmed by inoculating into CEF cell monolayer.

\section{Raising of hyperimmune serum against purified duck plague vaccine virus}

Four healthy un-vaccinated ducks of 3-4 months old were used to raise hyper-immune serum against the purified duck plague virus. Ducks were immunized repeatedly with $1 \mathrm{ml}$ of purified virus preparation containing 0.79 X $10^{4}$ TCID $_{50}$ virus particles. The schedule consisted of 4 injections. First injection was given in divided dose deep intramuscularly in thigh muscle, followed by three booster doses on $7^{\text {th }}, 14^{\text {th }}$ and $28^{\text {th }}$ days of primary vaccination through intramuscular route in thigh and breast muscle. After $10^{\text {th }}$ day of last injection, antibody level in the hyper immune serum was tested by indirect ELISA (Morrissy et al., 2004). Ducks showing 
desirable antibody titre were bled completely by exsanguination and serum was collected. Hyper immune sera aliquoted in $1 \mathrm{ml}$ volume were frozen at $-20^{\circ} \mathrm{C}$ for further use.

\section{Optimization of Indirect ELISA}

For detection of duck plague virus antibody indirect ELISA was standardized as per the method with little modification described by Morrissy and his co-workers (Morrissy et al., 2004). A chequer board titration was performed for optimization of working dilution of DPV antigen and antibodies as per standard protocols.

Briefly, 96 well ELISA plates (Polysorp, Nunc) were coated with $10 \mu \mathrm{g}$ purified attenuated DPV virus in carbonatebicarbonate buffer $(0.05 \mathrm{M}, \mathrm{pH}$ 9.6). Antigen was added to all the wells (Row 1 to Row 7) except antigen negative (Ag -ve) control wells (Row 8), where $50 \mu$ l of coating buffer was added. The plates were incubated overnight at $4^{\circ} \mathrm{C}$. After incubation, plates were washed thrice with washing buffer, PBS-T (0.5M PBS containing $0.05 \%$ Tween 20). After thorough washing pre-blocking was done using blocking buffer containing 5\% BSA and 2\% LAH @ $50 \mu 1$ to each well and the plate was kept for 1 hour at $37^{\circ} \mathrm{C}$. Two fold serial dilution of serum samples were made in blocking buffer and added in 50 $\mu 1$ volume and incubated. Controls included positive and negative sera: a) $50 \mu \mathrm{l}$ of diluted hyper immune serum to each well of row 6 ; b) $50 \mu \mathrm{l}$ of negative serum to each well of row 7 . After incubation, unbound antibodies were washed thrice with washing buffer and a volume of $50 \mu 1$ diluted anti duck HRPO conjugate (KPL, USA) diluted in wash buffer @1:200 was added to each well and incubated at $37^{\circ} \mathrm{C}$ for 1 hour. After washing $50 \mu \mathrm{l}$ of freshly prepared OPD substrate $+\mathrm{H}_{2} \mathrm{O}_{2}$ solutions was added to each well. After 15-20 minutes of incubation, colour reaction was stopped by adding equal volume of $1 \mathrm{M} \mathrm{H}_{2} \mathrm{SO}_{4}$ to all the wells. Optical density (O.D.) of the wells measured at $492 \mathrm{~nm}$ in ELISA reader (Biorad, USA). Cut-off value was calculated based on negative serum reactivity as follows: (Mean OD value of test sample - Mean OD of negative sample) more than equal $\geq 0.1$ OD was considered as end point of serum dilution.

\section{Results and Discussion}

The adaptation of the DPV vaccine strain in CEF primary cells and detection of the viral DNAs in the infected cells by PCR has been reported earlier (Mondal et al., 2010, Doley et al., 2013). In this study also PCR amplification of DNA polymerase gene (UL30) of DPV showed specific band of 446 bp at different passages in CEF primary cells (Fig. 1). CEF cell monolayer infected with the DP vaccine virus showed cytopathic changes from $3^{\text {rd }}$ passage onwards. Cytopathic effects (CPE) comprised of rounding of cells, formation of syncytia, marked cytoplasmic granulations, formation of large number of intracellular vacuoles (Fig. 2-4). CPE was visible 24 hour post inoculation (p.i) and completed within 72 hours post inoculation. In the present study, results showed that PEG concentration followed by sucrose gradient centrifugation was suitable for purification of DPV. Purification of duck plague virus by tangential flow filtration followed by ultracentrifugation was reported by other workers (Guo et al., 2009). It was also reported by other workers that aggregation of virus using PEG is gentle which does not affect in infectivity of virus in comparison to direct ultracentrifugation and 100 percent recovery of infectivity has been reported by using PEG for concentration of bovine viral diarrhoea virus (Clegg et al., 1985, Magar and Lecomte, 1987). After centrifugation in sucrose gradients altogether three sharply separated opalescent bands were observed in the tube viz. F1, F2, and F3, the F1 being at the top. 
Table.1 Sero prevalence of DPV antibody in different districts of Assam assayed by indirect ELISA

\begin{tabular}{|c|c|c|c|c|c|c|}
\hline \multirow[t]{2}{*}{$\begin{array}{l}\text { Sl. } \\
\text { No. }\end{array}$} & \multirow[t]{2}{*}{$\begin{array}{l}\text { Place of } \\
\text { collection }\end{array}$} & \multirow{2}{*}{$\begin{array}{l}\text { No. of } \\
\text { sample } \\
\text { tested }\end{array}$} & \multicolumn{3}{|c|}{$\begin{array}{l}\text { No. positive in ELISA (\% positivity) } \\
\text { at different titre }\end{array}$} & \multirow{2}{*}{$\begin{array}{c}\text { Total } \\
\text { seropositive } \\
(\%)\end{array}$} \\
\hline & & & $1: 80$ & $1: 160$ & $1: 320$ & \\
\hline 1. & Kamrup & 126 & 35 & 40 & 15 & $90(71.43)$ \\
\hline 2. & Nalbari & 76 & 29 & 5 & 15 & $49(64.47)$ \\
\hline 3. & Barpeta & 20 & 7 & 5 & 1 & $13(65.00)$ \\
\hline 4. & Nagaon & 31 & 9 & 12 & 0 & $21(67.74)$ \\
\hline 5. & Silchar & 34 & 2 & 15 & 3 & $20(58.82)$ \\
\hline 6. & Kokrajhar & 59 & 8 & 17 & 10 & $35(59.32)$ \\
\hline 7. & Dhemaji & 18 & 9 & 0 & 2 & $11(61.12)$ \\
\hline 8. & Dhubri & 23 & 4 & 5 & 5 & $14(60.86)$ \\
\hline 9. & Dibrugarh & 35 & 4 & 10 & 9 & $23(65.71)$ \\
\hline 10. & Morigaon & 23 & 12 & 3 & 0 & $15(65.22)$ \\
\hline & Total & 445 & $\begin{array}{c}119 \\
(26.74)\end{array}$ & $\begin{array}{c}112 \\
(25.17)\end{array}$ & $\begin{array}{c}60 \\
(13.48)\end{array}$ & $\begin{array}{c}291 \\
(65.39)\end{array}$ \\
\hline
\end{tabular}

$446 \mathrm{bp}$

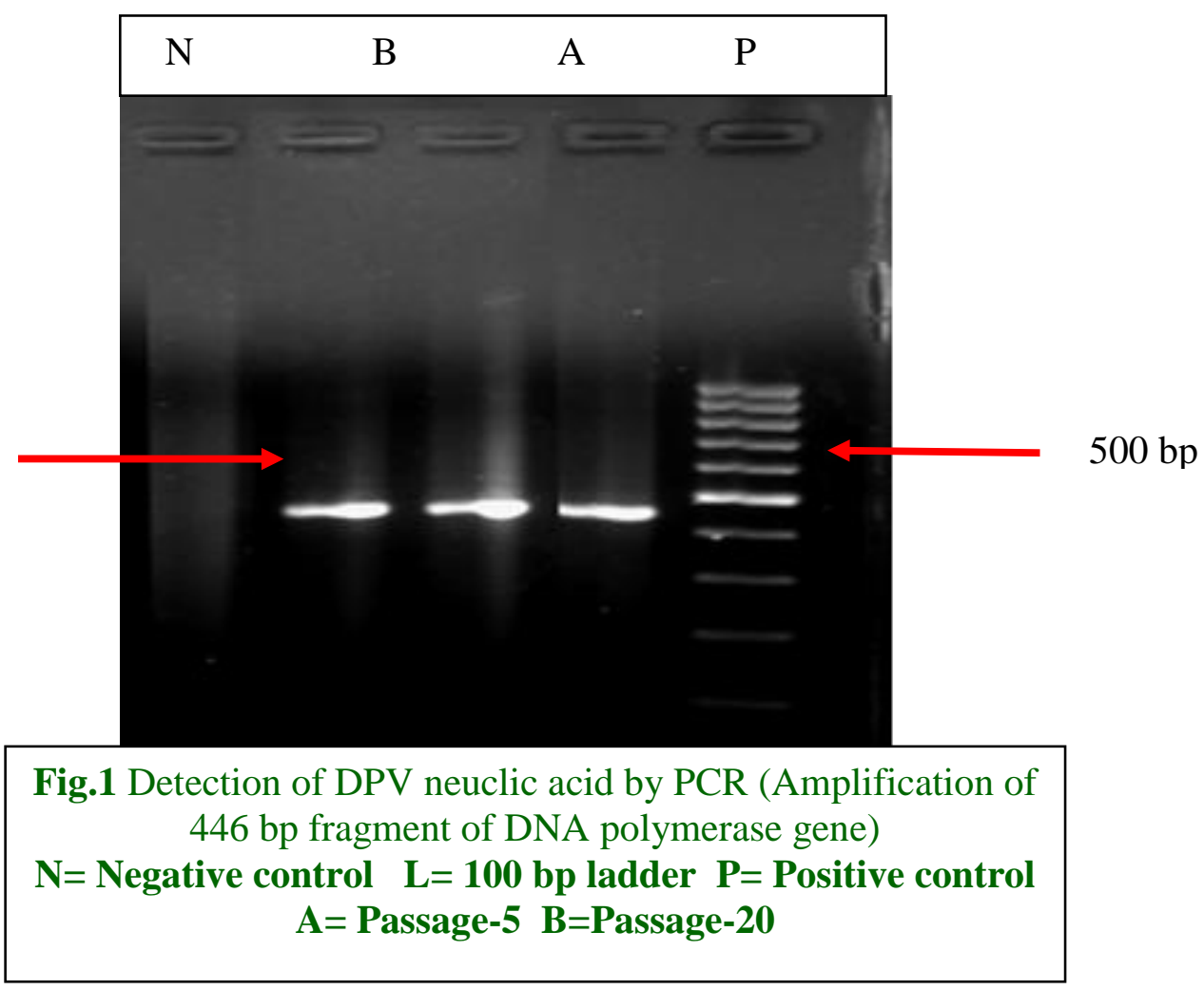




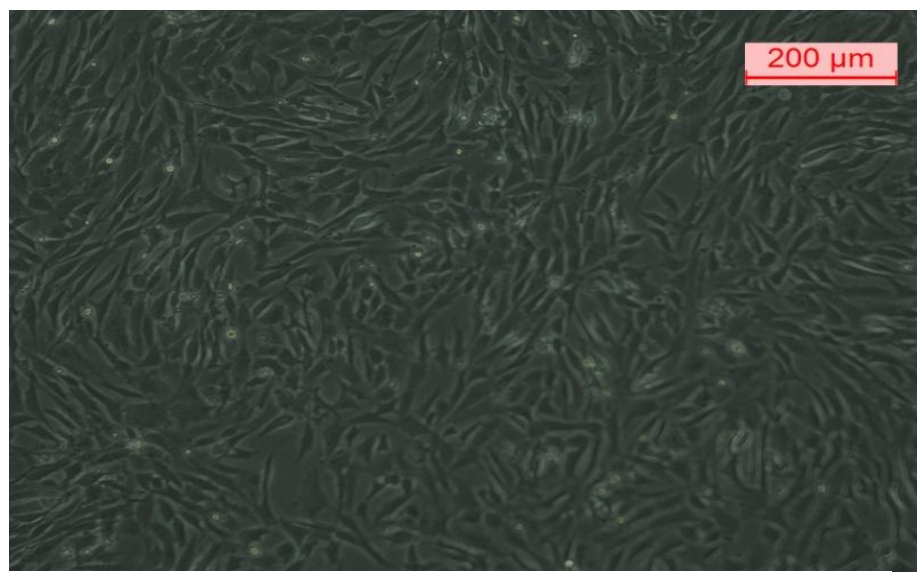

Fig.2 24 Hour confluent monolayer of CEF cells under phase contrast microscope (100X)

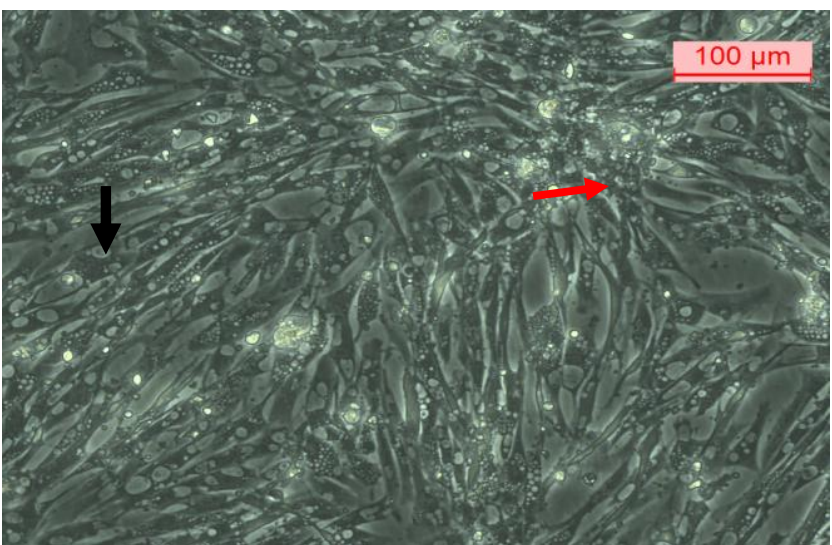

Fig.3 CEF cells showing increased granulation of cytoplasm (Black arrow) and Syncytia formation (Red arrow) at 36 hour post infection $(100 X)$

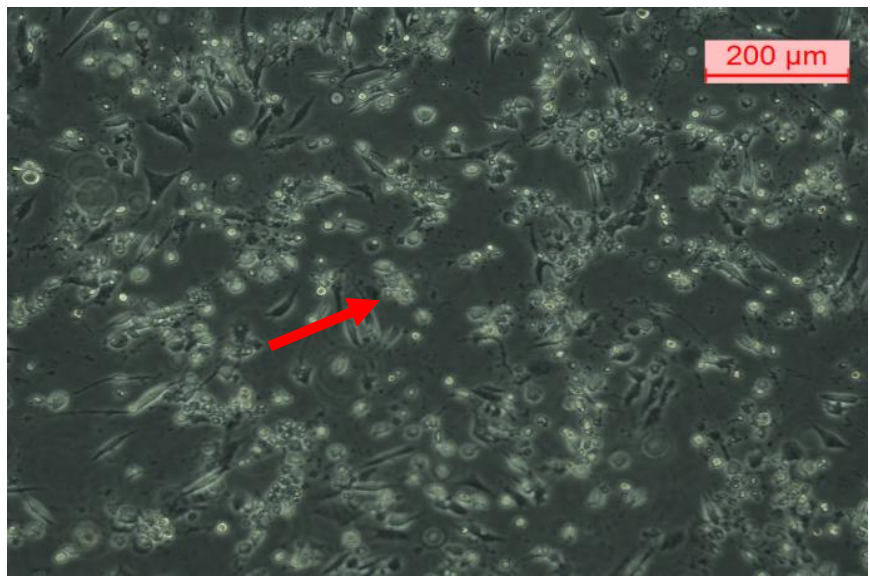

Fig.4 Rounding of cell with complete sloughing at 48 hour post infection (100X)

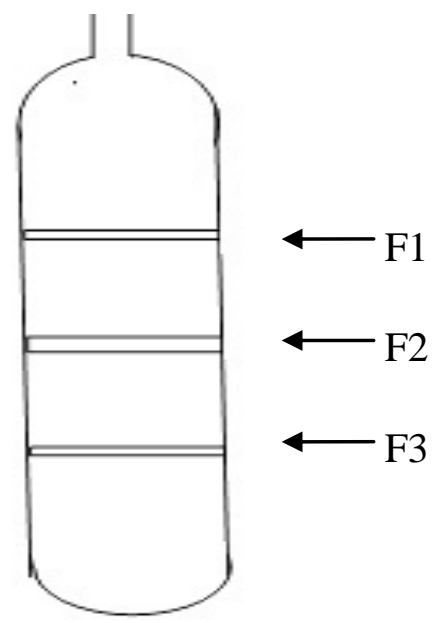

Fig.5 Schematic diagram showing the different bands of purified duck plague virus observed in sucrose gradients 


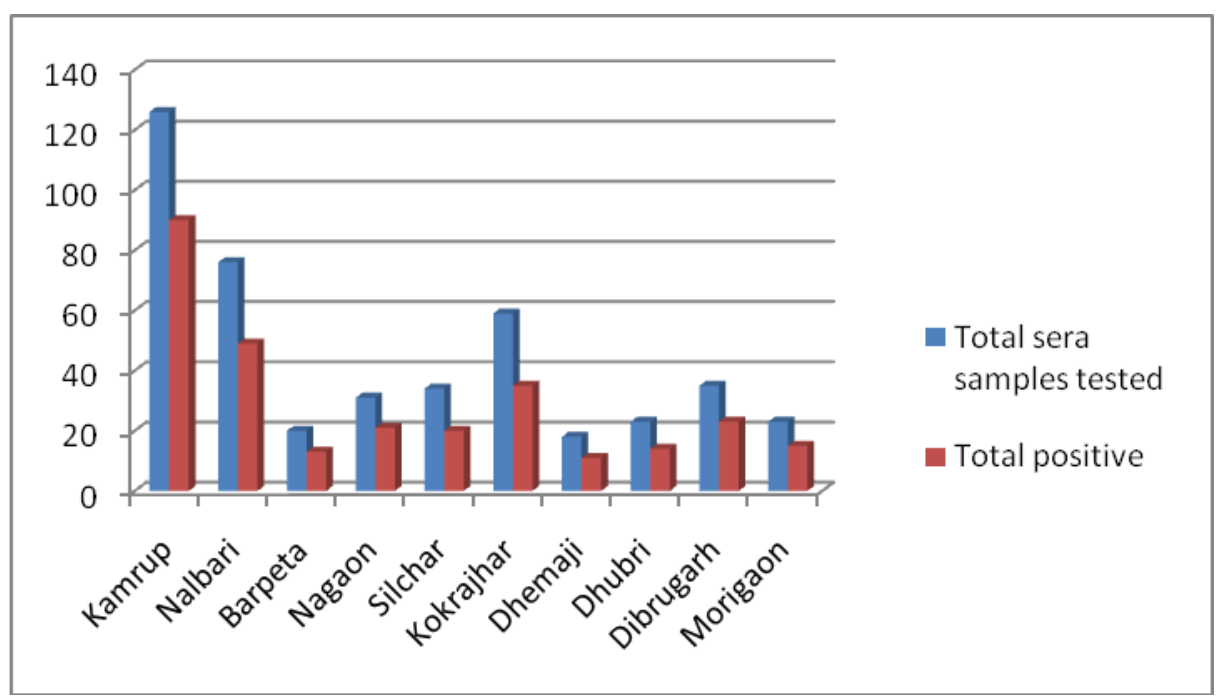

Fig.6 Graphical representation of district wise prevalence of DPV antibody in Assam (2014-2015)

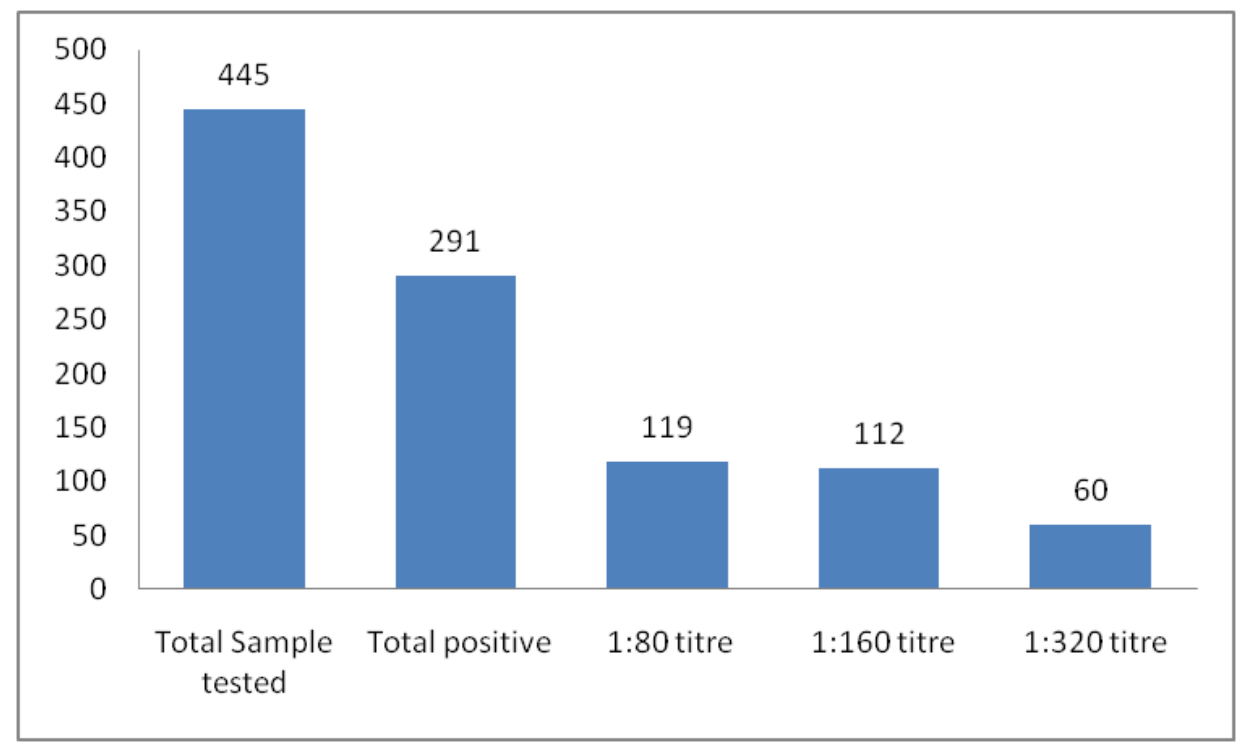

Fig.7 Graphical representation of percent positivity of dpv antibody at various titre level

The F2 fraction was more prominent than other two fractions and was observed almost between the sucrose gradient of 40 percent and 50 percent (Fig. 5). Further, the viability was assayed in CEF cell culture and it was found that the fraction F2 contained the viable virus. The virus pellet was finally suspended in required volume of $0.15 \mathrm{M}$ PBS ( $\mathrm{pH} 7.2)$ and stored at $-80^{\circ} \mathrm{C}$ till further use.
In our study, indirect ELISA was optimized to screen the prevalence of duck plague in duck population of Assam. Although, in the investigation, all the districts could not be covered, the study covering the areas depicts a clear picture of seropositivity of DPV antibodies among the duck population. The presence of DPV specific antibody in sera indicates the occurrence of duck plague in ducks as they were never vaccinated against 
this virus. A total of 445 blood samples were collected from unvaccinated apparently healthy ducks from 10 districts of Assam. Out of which 291 were found positive for DPV antibody and percent positivity was $65.39 \%$. Highest number of samples having positive DP viral antibody was recorded from Kamrup district of Assam (90/126) with a percent prevalence of $71.43 \%$ and lowest was recorded from Silchar district of Assam (20/34) with a percent prevalence of $58.82 \%$ (Table 1 and Fig. 6). Among the 291 positive serums 119 (26.74\%) showed 1:80 titre, 112 $(25.17 \%)$ showed 1:160 titre and $60(13.48 \%)$ showed 1:320 titre (Fig. 7). Indirect ELISA had been employed as a diagnostic tool for the detection of antibodies against various viral infections in sero-epidemiological surveys (Bhanuprakash et al., 2006; Balamurugan et al., 2007; Bora et al., 2007). Duck plague is endemic in India particularly in Assam. Different outbreaks were reported from various parts of India including Assam (Mukherji et al., 1963; Duraiswami et al., 1979; Rajan et al., 1980; Kulkarni et al., 1995; Konch et al., 2009; Doley, 2012) but no information about sero-prevalence of duck plague is available in India. In India several outbreaks go unrecorded due to underreporting/ no reporting and plenty of outbreaks have occurred in the past and are now occurring regularly throughout Assam. The prevalence of duck plague viral antibodies in unvaccinated ducks indicated not only subclinical or inapparent infection but also, nonlethal clinical infection or in other words recovered infected ducks, which could be of epidemiological significance.

In conclusion, the present study showed that duck plague is widely prevalent in duck population of Assam. The highly sensitive and specific I-ELISA test helps in screening of duck plague viral antibody in serum samples. The presence of duck plague viral antibodies in ducks indicates that the population was exposed to DPV infection naturally, either directly or indirectly. Depiction of sero-epidemiology of duck plague in Assam was a significant outcome of the study as there was no report on prevalence data. However, collection of more number of samples from all parts of Assam will elucidate the exact epidemiological picture of duck plague (DP).

\section{Acknowledgement}

The present work was supported by the Department of Biotechnology, Government of India, under DBT twinning programme for the NE "Development of novel molecular diagnostics and improved vaccine for Duck Plague Virus" (vide file No. 99/DRV/156/2013-14). Authors are also thankful to Department of Microbiology, College of Veterinary science, AAU, Khanapara, Assam for providing facilities for the study.

\section{References}

Ahamed, M.M., Hossain, M.T., Rahman, M., Nazir, K.H.M.N.H., Khan, M.F. R., Parvej, M.S., Ansari, W.K., Noor-AAlahi Chiste, M.N., Amin, K.B., Hossen, M.L., Ahmed, S. and Rahman, M.B. Molecular characterization of Duck Plague virus isolated from Bangladesh. J. Adv. Vet. Anim. Res., 2015; 2(3): 296-303.

Aravind, S., Kamble, N.M., Gaikwad, S.S., Shukla, S.K., Dey, S. and Mohan, C.M. Adaptation and growth kinetics study of an Indian isolate of virulent duck enteritis virus in Vero cells. Microb Pathog., 2015; 78:14-9.

Balamurgan, V., Singh, R.P., Saravanam, P., Sen, A., Sarkar, J., Sahey, B., Rasool, T.J. and Singh, R.K. Development of an Indirect ELISA for the detection of antibodies against Pestes-des-ruminants virus in small animals. Vet. Res. 
Commun., 2007; 31: 355-364.

Baudet, A. E. R. F. Mortality in ducks in the Netherlands caused by a filterable virus Fowl plague. Tijdschr Diergeneeskd, $1923 ; 50: 455-459$.

Bhanuprakash, V., Indrani, B.K., Hosamani, M. and Singh, R.K. The current status of sheep pox disease. Comp. Immun. Microb. Infec. Dis., 2006; 29: 27-60.

Bora, M., Bora, D.P., Barman, N.N., Borah, B. and Das, $S$. Seroprevalence of contagious ecthyma in Goats of Assam: An analysis by indirect enzyme linked immunosorbent assay. Vet. World, 2016; 9 (9):19.

Campagnolo, E.R.; Banerjee, M.; Panigraphy, B. and Jones, R.L. An outbreak of duck viral enteritis (duck plagues) in domestic Muscovy ducks (Cairina moschata domesticus) in Illinois. Avian Dis., 2001: 45, 522-528.

Chakravarty, A.K., Dutta, B.M., Mukit, A., Boro, B.R. and Bhattacharya, M.L. An outbreak of duck plague virus in Assam. J. Res. Assam Agric.Univ., 1980; 1: $72-$ 78.

Clegg, J.C.S. and Gould, E.A. Growth, Assay and Purification of Toga viruses. In: virology- a practical approach. (Mahy BWJ, ed) IRL press, Oxford, Washington DC, USA, 1985.

Doley, M. (2012). Molecular and antibody based diagnosis of duck plague virus infection from field outbreaks. M.V.Sc. thesis submitted to Assam Agricultural University, C.V.Sc., Khanapara, Guwahati-22.

Doley, M., Das, S.K., Barman, N.N. and Rajbongshi, G. Adaptation of vaccine strain of duck plague virus in chicken embryo fibroblast cell culture. Ind. J. ani. Sci., 2013; 83(9): 880-882.

Duraiswami, J., Rajendran, M.P., John, M., Ganesmurthy, M. and Rao, C.V.N. Duck plague in TamilNadu. Indian vet.J., 1979; 56:1-5.

El-Samadony, H.A., Tantawy, L.A., Salama, E and Khedr, A.A. Molecular Characterization of Circulating Duck
Viral Enteritis in Egypt during 20122013. British J. Poult. Sci., 2013; 2 (3): 38-44.

Fadly, A.M., Glisson, J.R., McDougald, L.R., Nolan, L.K. and Swayne, D.E.: Duck Virus Enteritis. In: Diseases of Poultry, 12 ed. (Saif YM, ed) American, WileyBlackwell, 2008; pp 384-393.

Fukuchi, F., Sudo, M., Lee, Y.S., Tanaka, A. and Nonoyama, M. Structure of Marek's disease virus DNA: detailed restriction map. J. Virol., 1984; 51: 102-109.

Guo, Y.F., Cheng, A.C., Wang, M.S. and Zhou. Y. Purification of anatid herpesvirus 1 particles by tangential-flow ultrafiltration and sucrose gradient ultracentrifugation. J. Virol. Meth., 2009; 161: 1-6.

Jansen J. Duck plague. American Veterinary Medical Association 1968; 152:10091016.

Jansen, J. Duck plague. British Vet.J., 1961; 117: 349-356.

John, K., Sarma, D.K., Boro, B.R. and Barman, N.N. Isolation and adaptation of a duck plague virus strain. Indian J. Ani. Sci,. 1990; 60(2): 503-506.

Kaleta, E. F., Kuczka, A., Kuhnhold, A., Bunzenthal, C., Bonner, B. M., Hanka, K., Redmann, T. and Yilmaz, A. Outbreak of duck plague (duck herpesvirus enteritis) in numerous species of captive ducks and geese in temporal conjunction with enforced biosecurity (in-house keeping) due to the threat of avian influenza A virus of the subtype Asia H5N1. Dtsch. Tierarztl. Wochenschr., 2007; 114:3-11.

King, A.M.Q., Adams, M.J., Carstens, E.B. and Lefkowitz, E. J. Ninth Report of the International Committee on Taxonomy of Viruses. Elsevier Academic Press, San Diego, 2012;pp 1344.

Konch, C., Upadhyaya T.N., Goswami S. and Dutta, B. Studies on the incidence and pathology in naturally occurring Duck plague in Assam. Indian J. Vet. Pathol., 2009; 33(2): 213-215.

Kulkarni, D.D., James, P.C. and Sulochana, S. 
Isolation of duck plague virus from ducks in Kerala state. Indian Vet J.,1995; 72: 446-50.

Leibovitz, L.: Duck plague (duck virus enteritis). In: Diseases of Poultry, 8th ed. (Hofstad MS, Calnek BW, Barnes $\mathrm{HJ}$, Beard CN, Reid WM and Yoder HW, ed) Ames, Iowa State University Press, 1984; 543-552.

Magar, R. and Lecomte, J. Comparision of methods for concentration and purification of bovine virus diarrhoea virus. J. Virol Meth., 1987;16 (4): 27179.

Mondal, B., Rasool, T.J., Ram, H. and Mallana, S. Propagation of Vaccine strain of Duck virus enteritis in a cell line of duck origin as an alternative production system to Propagation in embryonated egg, Bilogicals. 2010; 38: 401-406.

Morrissy, C.J., Daniels, S.L., Lowther, S.L., Goff, W., Pritchard, I., Tu, T.D., Phuc, K.V., Hung, D., Hong, N.T.L., Trung, N.T., Spradbrow, P.B. and Westbury, H.A. Duck plague in Vietnam and the development of diagnostic capability. In: ACIAR Proceeding No.117, Control of Newcastle disease and duck plague in village poultry. (Meers J, Spradbrow PB and $\mathrm{Tu} \mathrm{TD}$, ed). Canberra, Australia, Australian centre for International Agricultural research, 2004; pp 25-29.

Mukherji, A., Das, M.S., Ghosh, B.B. and
Ganguly, J.L. Duck Plague in West Bengal. Part 1. Indian Vet. J., 1963; 40:457-62.

Narhari D. Housing and management of ducks, IV World Waterfowl Conference, Thrissur, India, 2009; 45-47.

Office of International des Epizooties, Principle of validation of diagnostics assays for infectious disease, Chapter 1.14., 2008; pp 190-217.

Rajan, A., Nair, M.K., Maryama, K.I. and Valsala, K.V. Studies on epidemiology, symptoms and pathoanatomy of duck plague identification (Duck virus enteritis). Ind. Vet. J., 1980; 57: 12-15.

Rajput DS, Singh SP, Ghosh S, Nema RP. Duck Farming, Fascinating Option in India. Journal of Veterinary Science and Technology 2014; 5:3.

Richther, J. H.M. and Horzinek, M.C.: Duck Plague. In: Virus Infections of Birds, (McFerran JB and McNulty MS, ed) Elsevier Science Publishers B.V., Amsterdam, Netherlands, 1993; pp 7790.

Shawky, S. A. and Schat, K.A. Latency sites and reactivation of duck enteritis virus. Avian Dis., 2002; 46, 308-313.

Wang G, Qu Y, Wang F, Hu D, Liu L, Li N et al. The comprehensive diagnosis and prevention of duck plague in northwest Shandong province of China. Poultry Science 2013; 92: 2892-2898.

\section{How to cite this article:}

Samsun Neher, Nagendra N. Barman, Durlav P. Bora, Hiramoni Sarmah, Sophia M. Gogoi, Kongkon Baruah, Sukanya Buzarbaruah, Parag J. Saharia and Sailendra K. Das. 2019. Duck Plague Virus Antibodies: An Analysis by Indirect ELISA in Duck Population of Assam. Int.J.Curr.Microbiol.App.Sci. 8(03): 1919-1928. doi: https://doi.org/10.20546/ijcmas.2019.803.228 